DOI: https://doi.org/10.15688/jvolsu11.2018.2.9

UDC 595.775:616.98-036.21:579.842.23

LBC 28.0

\title{
THE DOMINANCE INDICES AND THE PROBABILITY TO INVOLVE DIFFERENT FLEAS TYPES IN EPIZOOTIC DISEASES ON THE EXAMPLE OF CENTRAL-CAUCASIAN HIGH-MOUNTAIN NATURAL PLAGUE FOCUS
}

\author{
Yuri M. Evchenko \\ Stavropol Anti-plague Institute, Stavropol, Russian Federation \\ Tatyana V. Zharnikova \\ Stavropol Anti-plague Institute, Stavropol, Russian Federation \\ Irina V. Zharnikova \\ Stavropol Anti-plague Institute, Stavropol, Russian Federation \\ Irina N. Zaikina \\ Stavropol Anti-plague Institute, Stavropol, Russian Federation \\ Marina E. Mikhailova \\ Stavropol Anti-plague Institute, Stavropol, Russian Federation \\ Tatyana V. Taran \\ Stavropol Anti-plague Institute, Stavropol, Russian Federation \\ Natal'ya M. Shvetsova \\ Stavropol Anti-plague Institute, Stavropol, Russian Federation \\ Svetlana G. Tkhakumasheva \\ Kabardino-Balkar anti-plague Station, Nalchik, Kabardino-Balkar Republic, Russian Federation
}

Abstract. The paper attempts to use an indicator of the number of fleas of different species in the natural focus of the plague to assess the intensity of epizootics. The correlation between the number of fleas of seven species and the number of isolated strains of plague microbe is established. It is shown for small species to be more often involved in epizootics during their intensive course, which corresponded to the first period of the focus activity. In the second period characterized the tendency to decrease the share of small species in the epizootic process. The third period demonstrated a significant difference with the first two previous ones. The detection in samples of field material of infected secondary carriers of these species or random carriers was indirect evidence of intense epizootics. analysis.

Key words: epizootics of plague, the carriers of plague, fleas, natural focal infection, quantitative 


\title{
ИНДЕКСЫ ДОМИНИРОВАНИЯ И ВЕРОЯТНОСТЬ ВОВЛЕЧЕНИЯ РАЗНЫХ ВИДОВ БЛОХ В ЭПИЗООТИИ НА ПРИМЕРЕ ЦЕНТРАЛЬНО-КАВКАЗСКОГО ВЫСОКОГОРНОГО ПРИРОДНОГО ОЧАГА ЧУМЫ
}

\author{
Юрий Михайлович Евченко \\ Ставропольский противочумный институт Роспротребнадзора, г. Ставрополь, Российская Федерация \\ Татьяна Владимировна Жарникова \\ Ставропольский противочумный институт Роспротребнадзора, г. Ставрополь, Российская Федерация
}

Ирина Викторовна Жарникова

Ставропольский противочумный институт Роспротребнадзора, г. Ставрополь, Российская Федерация

Ирина Николаевна Заикина

Ставропольский противочумный институт Роспротребнадзора, г. Ставрополь, Российская Федерация

Марина Евгеньевна Михайлова

Ставропольский противочумный институт Роспротребнадзора, г. Ставрополь, Российская Федерация

Татьяна Викторовна Таран

Ставропольский противочумный институт Роспротребнадзора, г. Ставрополь, Российская Федерация

Наталья Михайловна Швецова

Ставропольский противочумный институт Роспротребнадзора, г. Ставрополь, Российская Федерация

\author{
Светлана Абдуловна Тхакумашева \\ Кабардино-Балкарская противочумная станция, \\ г. Нальчик, Кабардино-Балкарская Республика, Российская Федерация
}

Аннотация. В работе предпринята попытка использования в природном очаге чумы показателя численности блох различных видов для оценки интенсивности эпизоотии. Установлена корреляция между численностью блох семи видов и количеством выделенных от них штаммов чумного микроба. Показано, что малочисленные виды чаще вовлекаются в эпизоотии при интенсивном их течении, что соответствует первому периоду активности очага. Во втором периоде определяется тенденция к снижению доли участия малочисленных видов в эпизоотическом процессе. В третьем периоде видна существенная разница с первыми двумя периодами. Обнаружение в пробах полевого материала зараженных второстепенных переносчиков указанных видов или случайных носителей и переносчиков является косвенным свидетельством интенсивной эпизоотии.

Ключевые слова: эпизоотии чумы, переносчики чумы, блохи, природно-очаговые инфекции, количественный анализ.

Оценка интенсивности эпизоотий имеет значение при планировании и проведении профилактических мероприятий с учетом их своевременности, полноты и достаточности. Для оценки интенсивности эпизоотий используется ряд количественных показателей $[3 ; 6]$.
Кроме количественных показателей для каждого природного очага чумы должны быть разработаны конкретные прогностические признаки, которые позволяют предвидеть текущие изменения эпизоотической активности очага $[1 ; 7]$. 
Целью данного исследования было установить возможность использования в качестве признака активной эпизоотии участие в ней видов блох с низкой численностью.

Сведения о выделенных штаммах чумного микроба в Центрально-Кавказском высокогорном природном очаге за период с 1971 по 2007 гг. взяты из официальных форм отчетности ФКУЗ «Кабардино-Балкарская противочумная станция».

Определялась корреляции между численностью блох разных видов и частотой вовлечения их в эпизоотический процесс в условиях Центрально-Кавказского высокогорного природного очага чумы. Соотношение блох в сборах полевого материала выражается в индексах доминирования. Индекс доминирования отражает отношение числа особей какого-либо вида к общему числу особей других видов в биоценозе.

Нами установлена статистически значимая корреляция $\left(r_{s}=0.893\right)$ числа экземпляров блох разных видов (Citellophilus tesquorum, Neopsylla setosa, Frontopsylla semura, Oropsylla idahoensis ilovaiskii, Rhadinopsylla li, Ctenophthalmus golovi, Ctenophthalmus orientalis) с количеством выделенных от них штаммов чумного микроба. Из этого следует, что вероятность обнаружения зараженных блох определенного вида тем выше, чем больше их численность. Блохи многочисленного вида, такого как Cit. tesquorum, обнаруживаются зараженными значительно чаще, чем особи малочисленных видов такого, например, как Rh. li.

Установлено, что индексы доминирования блох разных видов, отловленных во входах нор, коррелируют с количеством выделенных от них штаммов чумного микроба $\left(r_{s}=0.886\right)$.

Далее была изучена зараженность блох разных видов в разные периоды активности очага [5]. Первый период (1971 по 1981 гг.) характеризуется наибольшей активностью эпизоотий, во второй период (1982-2000 гг.) она существенно снижена за счет мероприятий по регулированию численности носителей и переносчиков чумы, а в третьем (2001-2007 гг.) отмечается депрессия очага.

Установлено, что малочисленные виды чаще вовлекаются в эпизоотии при интенсивном их течении, то есть в первый период активности очага. Во втором периоде определяется тенденция к снижению доли участия ма- лочисленных видов в эпизоотическом процессе. В третьем периоде видна существенная разница с первыми двумя периодами. За 15 лет течения этого периода не обнаружено зараженных блох видов Fr. semura, Or. iloveiskii u Rh. li. Снижены доли Ct. golovi, Ct. orientalis, $N$. setosa. При этом доля Cit. tesquorum увеличилась до 90 \%. В последнее время появились работы, частично объясняющие механизмы развития подобного феномена [2; 4].

Таким образом, интенсивные эпизоотии, активизирующие механизм передачи возбудителя чумы, сопровождаются вовлечением в эпизоотический процесс второстепенных переносчиков Fr. semura, Or. iloveiskii и Rh. li, численность которых характеризуется низкими индексами доминирования, а также случайных носителей и переносчиков. Обнаружение в пробах полевого материала зараженных второстепенных переносчиков указанных видов или случайных носителей и переносчиков является косвенным свидетельством интенсивной эпизоотии.

\section{СПИСОК ЛИТЕРАТУРЫ}

1. История эпидемий чумы на Северном Кавказе и современный эпидемический потенциал природных очагов чумы / Е. С. Котенев, В. М. Дубянский, А. С. Волынкина [и др.] // Медицинский вестник Северного Кавказа. - 2016. - Т. 11, № 4. C. 612-616.

2. Кошель, Е. И. Характеристика нового полигостального вида энтомопаразитических нематод возможного регулятора численности блох в очагах чумы / Е. И. Кошель, Г. А. Ерошенко, В. В. Кутырев // Медицинская паразитология и паразитарные болезни. - 2018. -№ 2. - С. 28-35.

3. Попов, Н. В. Оценка численности блох (Insecta, Siphonaptera) в период развития эпизоотий чумы в степных природных очагах сусликового типа северного и северо-западного Прикаспия и Предкавказья / Н. В. Попов, В. В. Аникин, А. И. Удовиков // Труды Русского энтомологического общества. - 2014. - Т. 85, № 2. - С. 47-52.

4. Современное состояние численности блох P. irritans и их эпизоотологическая и эпидемиологическая значимость в условиях Алайского природного очага чумы / К. И. Алтыбаев, С. Т. Абдикаримов, С. К. Бердиев, К. К. Шекеев // Здравоохранение Кыргызстана. - 2017. - № 4. - С. 15-18.

5. Эпизоотическая активность ЦентральноКавказского высокогорного природного очага 
чумы / А. Н. Куличенко, Ю. М. Евченко, Г. А. Мозлоев [и др.] // Проблемы особо опасных инфекций. 2011. - № 4. - С. 23-26.

6. Eisen, R. J. The role of early-phase transmission in the spread of Yersinia pestis / R. J. Eisen,
D. T. Dennis, K. L. Gage // J. Med. Entomol. - 2015. Vol. 52, № 6. - P. 1183-1192.

7. Interdisciplinary approaches to zoonotic disease / R. Goodwin, D. Schley, K.-M. Lai [et al.] // Infect. Dis. Rep. - 2012. - Vol. 4, № 2. - e37.

\section{Information about the Authors}

Yuri M. Evchenko, Epidemiologist, Stavropol Anti-plague Institute, Sovetskaya St., 13-15, 355035 Stavropol, Russian Federation, evchenko-1952@mail.ru.

Tatyana V. Zharnikova, Epidemiologist, Stavropol Anti-plague Institute, Sovetskaya St., 13-15, 355035 Stavropol, Russian Federation, stavnipchi@mail.ru.

Irina V. Zharnikova, Epidemiologist, Stavropol Anti-plague Institute, Sovetskaya St., 13-15, 355035 Stavropol, Russian Federation, stavnipchi@mail.ru.

Irina N. Zaikina, Epidemiologist, Stavropol Anti-plague Institute, Sovetskaya St., 13-15, 355035 Stavropol, Russian Federation, stavnipchi@mail.ru.

Marina E. Mikhailova, Epidemiologist, Stavropol Anti-plague Institute, Sovetskaya St., 13-15, 355035 Stavropol, Russian Federation, stavnipchi@mail.ru.

Tatyana V. Taran, Epidemiologist, Stavropol Anti-plague Institute, Sovetskaya St., 13-15, 355035 Stavropol, Russian Federation, stavnipchi@mail.ru.

Natal'ya M. Shvetsova, Epidemiologist, Stavropol Anti-plague Institute, Sovetskaya St., 13-15, 355035 Stavropol, Russian Federation, stavnipchi@mail.ru.

Svetlana G. T khakumasheva, Epidemiologist, Kabardino-Balkar Anti-plague Station, Baisultanov St., 35, 360000 Nalchik, Kabardino-Balkar Republic, Russian Federation, kbpchs07@mail.ru.

\section{Информация об авторах}

Юрий Михайлович Евченко, врач-эпидемиолог, Ставропольский противочумный институт Роспротребнадзора, ул. Советская 13-15, 355035 г. Ставрополь, Российская Федерация, evchenko-1952@mail.ru.

Татьяна Владимировна Жарникова, врач-эпидемиолог, Ставропольский противочумный институт Роспротребнадзора, ул. Советская 13-15, 355035 г. Ставрополь, Российская Федерация, stavnipchi@mail.ru.

Ирина Викторовна Жарникова, врач-эпидемиолог, Ставропольский противочумный институт Роспротребнадзора, ул. Советская 13-15, 355035 г. Ставрополь, Российская Федерация, stavnipchi@mail.ru.

Ирина Николаевна Заикина, врач-эпидемиолог, Ставропольский противочумный институт Роспротребнадзора, Улица Советская 13-15, 355035, г. Ставрополь, Российская Федерация, stavnipchi@mail.ru.

Марина Евгеньевна Михайлова, врач-эпидемиолог, Ставропольский противочумный институт Роспротребнадзора, ул. Советская 13-15, 355035 г. Ставрополь, Российская Федерация, stavnipchi@mail.ru.

Татьяна Викторовна Таран, врач-эпидемиолог, Ставропольский противочумный институт Роспротребнадзора, ул. Советская 13-15, 355035 г. Ставрополь, Российская Федерация, stavnipchi@mail.ru.

Наталья Михайловна Швецова, врач-эпидемиолог, Ставропольский противочумный институт Роспротребнадзора, ул. Советская 13-15, 355035 г. Ставрополь, Российская Федерация, stavnipchi@mail.ru.

Светлана Абдуловна Тхакумашева, врач-эпидемиолог, Кабардино-Балкарская противочумная станция, ул. Байсултанова, 35, 360000 г. Нальчик, Кабардино-Балкарская Республика, Российская Федерация, kbpchs07@mail.ru 